\title{
Effects of different frozen storage conditions on the functional properties of wheat gluten protein in nonfermented dough
}

\author{
Lin ZHANG ${ }^{1}$, Jie ZENG ${ }^{1 \star}$ (D), Haiyan GAO $^{1}$, Keke ZHANG ${ }^{1}$, Mengyu WANG ${ }^{1}$
}

\begin{abstract}
The functional properties of wheat gluten protein isolated from nonfermented dough stored at $-6{ }^{\circ} \mathrm{C},-12{ }^{\circ} \mathrm{C},-18{ }^{\circ} \mathrm{C},-24{ }^{\circ} \mathrm{C}$ and $-30^{\circ} \mathrm{C}$ for $10 \mathrm{~d}, 20 \mathrm{~d}$ and $30 \mathrm{~d}$ were investigated. The solubility and water holding capacity of gluten protein decreased with decreasing frozen storage temperatures and increasing frozen storage time. The foamability of gluten protein was not affected by different frozen storage temperatures. However, the foamability of gluten protein decreased with extension of the frozen storage time. The storage modulus $\left(G^{\prime}\right)$ and loss modulus $\left(G^{\prime \prime}\right)$ of gluten decreased with decreasing frozen storage temperatures. Meanwhile, the storage modulus $\left(G^{\prime}\right)$ and loss modulus $\left(G^{\prime \prime}\right)$ of gluten increased with extension of the frozen storage time. When the frozen storage temperature of gluten was $-12^{\circ} \mathrm{C}$, the frozen water content was lower than that in gluten with other frozen storage temperatures. The water migration of gluten protein under different frozen storage temperatures and times was measured by low-field NMR. The microstructure of gluten protein was also observed under a scanning electron microscope. It was found that more serious damage to the gluten structure occurred with lower freezing temperatures and longer freezing times.
\end{abstract}

Keywords: gluten protein; functional properties; frozen storage temperature; frozen storage time.

Pratical Application: Control of quality of dough using freezing storage temperature.

\section{Introduction}

In recent years, the frozen flour products industry has grown rapidly. Frozen flour products include a wide variety of commodities, such as frozen steamed bread, fast-frozen dumplings, frozen pastries, and semimanufactured products such as frozen fermented dough and nonfermented dough, which need to be further processed into finished products (Zhao et al., 2021). Frozen flour products bring great convenience to people's lives. This convenience is favored by consumers. There is a growing demand for frozen flour products. Frozen rice products and wheat flour products account for $52.4 \%$ of frozen foods and are the largest category of frozen foods, and development of these product scales, brands, and chains has gradually become the main goal and general trend in the industry (Meng et al., 2021a). In the process of frozen dough storage, due to changes in the frozen storage temperature and time, the products will crack, shrink, collapse, and develop an uneven internal structure, poor taste, etc., resulting in poor sensory characteristics of the final product, reduced consumption, and limited large-scale application of frozen dough (Lu et al., 2021). Therefore, it is necessary to solve the key technical problems in the production of frozen flour products.

Dough is a complex system of gluten networks, starch, nonstarch polysaccharides, salt, sucrose and other components (Feng et al., 2020). Among the constituents, the gluten network is the framework of the system, and changes in the gluten protein directly affect the quality of dough (Zhao et al., 2016). In the dough mixing process, wheat flour is mixed with water to form gluten. Then, the gluten protein molecules absorb water and interact to form a three-dimensional network. This structure gives dough properties such as water retention, ductility and viscoelasticity (Zhou et al., 2020). During freezing, liquid water in the dough crystallizes to form solid ice. The number and size of ice crystals are important factors affecting the quality of frozen food. Ice crystals can damage the gluten protein network in two main ways. One is that during the initial freezing stage, the ice crystal content in the dough increases rapidly. At $-10^{\circ} \mathrm{C}$, approximately $55 \%$ of the water turns into ice. When the temperature is further reduced from $-20^{\circ} \mathrm{C}$ to $-40{ }^{\circ} \mathrm{C}$, the ice crystal content increases slightly (Wang et al., 2015). When water freezes as ice, its volume increases by approximately $9 \%$. As the ice crystals increase in volume, the gluten protein network is damaged. Second, in the process of frozen storage, small ice crystals gradually gather and minimize their interface to achieve a relatively stable state. This induces the gradual formation of large ice crystals. This process, called ice recrystallization, further destroys the gluten protein network (Bhattacharya et al., 2003). In addition, during the freezing process, water loss from the dough will also affect the functional properties of gluten, resulting in a decrease in the quality of the dough.

Experts and scholars at home and abroad have actively explored and studied the problems mentioned above in frozen flour products. Zhang et al. (2018) reported the influence of multiple freeze-thaw cycles on the quality of frozen dough. They also used ultrasound-assisted freezing to decrease freezing 
damage to the molecular structure of gluten protein (Zhang et al., 2020a). Liu et al. (2011) found that with extension of the frozen storage time, the solubility, water retention capacity, oil retention capacity, emulsification capacity, foaming and foam stability of wheat gluten decreased, but after freezing, the stability of the wheat gluten emulsion was improved. Yang et al. (2021a) studied the effects of the freezing rate on the structure of gluten protein in nonfermented dough. It was found that a slower freezing rate and longer storage time had the greatest influence on the texture and stability of unfermented dough. Freezing at $-40{ }^{\circ} \mathrm{C}$ $\left(0.149^{\circ} \mathrm{C} / \mathrm{min}\right)$ had the best overall effect on the rheology and protein structure of unfermented dough. Zhang et al. (2020b) extracted oat antifreeze protein and added it to gluten protein, thus improving the antifreeze ability of flour products. Lu et al. (2021) reported that adding $\mathrm{NaHCO}_{3}$ to dough reduced the content of freezable water, slowed the increase in water mobility during frozen storage, and enhanced the freezing-thawing resistance of dough. However, current research is mainly focused on the frozen storage time, freezing-thawing cycle, addition of biological or chemical antifreeze agents and freezing and thawing methods to improve the functional properties of gluten protein. However, there are still some questions that need to be addressed regarding frozen storage of flour products. What are the effects of different frozen storage temperatures and times on the functional properties of gluten? Is there a better frozen storage temperature than the conventional frozen storage temperature $\left(-18{ }^{\circ} \mathrm{C}\right)$ for maintaining the stability of gluten protein properties? There were fewer reports on these subjects. In this paper, the solubility, water holding capacity, foamability, foam stability, rheological properties, freezable water content, water migration and microstructure of gluten protein under different frozen storage conditions were investigated. This study provides a new idea and theoretical basis for the study of wheat gluten protein and frozen flour products.

\section{Materials and methods}

\subsection{Materials}

Wheat flour was purchased from Hebei Wudeli Co., Ltd., Hebei, China. Bovine serum protein was purchased from Nanjing Aodoforni Biotechnology Co., Ltd., Nanjing, China.

\subsection{Preparation of dough and the frozen storage design}

Five hundred grams of flour and $250 \mathrm{~g}$ of distilled water were mixed using a dough mixer (DL-C03 dough mixer, Dongling Electric Co., Ltd., Guangdong, China) for $7 \mathrm{~min}$ to form dough with a smooth surface. The dough was cut into small pieces of $50 \mathrm{~g}$ and formed into small round doughballs. The dough was quick-frozen at $-40^{\circ} \mathrm{C}$ for $45 \mathrm{~min}$ in a programmable cryogenic incubator (Hy-TH-80DH, Hongjin Testing Instrument Co., Ltd., Dongguan, China) and then transferred to another programmable cryogenic incubator for storage at $-6^{\circ} \mathrm{C},-12{ }^{\circ} \mathrm{C},-18{ }^{\circ} \mathrm{C},-24^{\circ} \mathrm{C}$ and $-30{ }^{\circ} \mathrm{C}$. Dough samples were frozen at different storage temperatures, stored for 10, 20 and 30 days and then removed for analysis.

\subsection{Preparation of wet gluten and gluten protein powder}

Wet gluten protein was prepared according to the method of Liu et al. (2016) with some modifications. The frozen dough was thawed for $1 \mathrm{~h}$ at room temperature. The dough was repeatedly kneaded with distilled water to remove the starch from the dough until iodine solution could be dropped into the water without the water turning blue, indicating that the starch had been removed from the dough. Wet gluten protein was obtained after this process. Then, the wet gluten protein was centrifuged at $3000 \mathrm{r} / \mathrm{min}$ for $20 \mathrm{~min}$ in a multifuge X1R desktop high-speed centrifuge (Thermo company, Massachusetts, USA). The supernatant was discarded.

A portion of the wet gluten protein was placed in a cryogenic incubator at $-40{ }^{\circ} \mathrm{C}$ and frozen for $45 \mathrm{~min}$. Then, it was freeze-dried for $48 \mathrm{~h}$ in an Aiphal-2LD plus Vacuum Freeze Dryer (Germany CHRIST Freeze Dryer Co., Ltd, Lower Saxony, Germany). The dried gluten protein was crushed and passed through a 100 mesh $(150 \mu \mathrm{m})$ sieve, and then the gluten powder was sealed in a plastic bag and stored in a glass dryer for later analysis.

\subsection{Solubility and water holding capacity of gluten protein}

The solubility of gluten protein was determined according to the method of Liu et al. (2011) with some modifications. Bovine serum protein was used to prepare the standard curve, and the standard curve formula was $y=0.516 x+0.0343\left(R_{2}=0.9957\right)$, where $\mathrm{x}$ is the absorbance and $\mathrm{y}$ is the protein concentration.

One gram of gluten powder was weighed and added to $99 \mathrm{~g}$ of distilled water to prepare a $1 \%$ gluten dispersion. The dispersion was stirred for $1 \mathrm{~h}$ on a ZNCL-B magnetic stirrer (Henan Abbot Technology Development Co., LTD., Zhengzhou, China) and then centrifuged at $3000 \mathrm{r} / \mathrm{min}$ for $20 \mathrm{~min}$ in an X1R desktop highspeed centrifuge (Thermo company, Massachusetts, USA), and the supernatant was obtained. A 752N UV-Visible Photometer (Shanghai Jingke Experiment Co., LTD., Shanghai, China) was used to measure the absorbance of the supernatant at $280 \mathrm{~nm}$. Then, the absorbance was substituted into the standard curve to calculate the protein content in the supernatant. The solubility of gluten protein was calculated according to Equation (1).

Solubility $=C_{1} / C_{2}$

Note: $\mathrm{C}_{1}$ is the protein content in the supernatant, $\mathrm{g} ; \mathrm{C}_{2}$ is the protein content in the dispersion solution, $\mathrm{g}$.

The water holding capacity of gluten protein was determined according to the method of Zhang et al. (2018). One gram of gluten powder was weighed and placed in a centrifuge tube, and then sufficient distilled water was added (more than $20 \mathrm{~mL}$ ). After continuous mixing with a glass rod for $20 \mathrm{~min}$, the gluten protein solution was centrifuged at $4500 \mathrm{r} / \mathrm{min}$ for $10 \mathrm{~min}$. The supernatant was discarded, and the precipitate was weighed. The water-holding capacity of gluten protein was calculated according to Equation (2).

Water holding capacity $=\left(m_{2}-m_{1}\right) / m_{1}$

Note: $\mathrm{m}_{1}$ is the sample weight, $\mathrm{g} ; \mathrm{m}_{2}$ is the precipitate weight, $\mathrm{g}$. 


\subsection{Foamability and foam stability of gluten protein}

The foamability and foam stability of gluten were determined by referring to the method of Wang et al. (2014). Gluten powder $(0.5 \mathrm{~g})$ was weighed and added to $99.5 \mathrm{~g}$ distilled water to prepare a $0.5 \%$ gluten dispersion. The dispersion was stirred for $1 \mathrm{~min}$ at $10000 \mathrm{r} / \mathrm{min}$ in an XHF-D high-speed disperser (Ningbo Xinzhi Biotechnology Co., LTD., Ningbo, China) and then quickly poured into a measuring cylinder to measure the foam volume. After the gluten protein dispersion was allowed to stand for $20 \mathrm{~min}$, the foam volume was measured again. The foamability and foam stability of gluten protein were calculated by Equation (3) and Equation (4).

Foamability $=V / 100 \times 100 \%$

Foam stability $=V_{e} / V \times 100 \%$

Note: $\mathrm{V}$ is the volume of foam when agitation was stopped, $\mathrm{mL}$; $\mathrm{V}_{\mathrm{e}}$ is the volume of foam after standing for $20 \mathrm{~min}, \mathrm{~mL}$.

\subsection{Rheological properties of gluten protein}

The rheological properties of gluten protein were determined by referring to the method of Meng et al. (2021b). One gram of wet gluten protein prepared in Section 2.3 was weighed, and its rheological properties were determined by a Haake Makers III 006-1576 Version 1.3 rotary rheometer (Thermo Scientific Company, Frankfort, Germany). Frequency scanning was carried out at $25^{\circ} \mathrm{C}$ with a $40-\mathrm{mm}$ circular flat plate probe with $1-\mathrm{mm}$ parallel plate spacing. The scanning frequency range was $0.1 \sim 10 \mathrm{~Hz}$, and the stress was $1 \%$. Curves of the storage modulus ( $\left.G^{\prime}\right)$ and loss modulus ( $\left.G^{\prime \prime}\right)$ as a function of frequency were obtained from the test.

\subsection{Freezable water content of gluten protein}

The freezable water content of gluten protein was measured by the method reported by Kontogiorgos et al. (2007). Ten to twenty milligrams of wet gluten prepared in Section 2.3 was weighed and sealed in a stainless-steel crucible (Shanghai Zhengji Scientific Instrument Co., LTD, Shanghai, China) and then measured with a Q200 differential scanning calorimeter (DSC) (TA Inc., USA). An empty stainless-steel crucible was used as the reference. The initial temperature was $25^{\circ} \mathrm{C}$, and the temperature was lowered to $-40^{\circ} \mathrm{C}$ at a rate of $5^{\circ} \mathrm{C} / \mathrm{min}$, maintained for $1 \mathrm{~min}$ at $-40{ }^{\circ} \mathrm{C}$, and then heated to $30^{\circ} \mathrm{C}$ at a rate of $5^{\circ} \mathrm{C} /$ $\mathrm{min}$. The nitrogen flow rate was $50 \mathrm{~mL} / \mathrm{min}$. TA Instruments analysis software (TA Instruments, New Castle, Delaware) was used to analyze the obtained curve by integrating the DSC results to scan the peak area of melting enthalpy. To reduce the error, each integration was started at the melting temperature of ice, $-10^{\circ} \mathrm{C}$, and ended at $20^{\circ} \mathrm{C}$.

\subsection{Water distribution and migration of gluten protein}

The water distribution and migration of gluten protein were determined by a low-field nuclear magnetic resonance imaging analyzer (NMI20-040V-I, Suzhou Niumag Analytical Instrument Co., Ltd., Jiangsu, China) according to the method of Jiang et al. (2021) with some modifications. Three grams of wet gluten prepared in Section 2.3 was weighed and placed in a $25 \mathrm{~mm}$-diameter MRI tube, and then the tube was placed in the center of an RF coil in the center of a permanent magnet field to conduct a CPMG (Carr-Purcell-Meiboom-Gill) pulse sequence test. The CPMG pulse sequence parameters were set as follows: sampling frequency (SW), $100 \mathrm{kHz}$; repeated scanning time (NS), 4; half echo time (TE), $0.8 \mathrm{~ms}$; and number of sampling points (TD), 400018 .

\subsection{Gluten protein microstructure determination by scanning electron microscopy}

The wet gluten prepared in Section 2.3 was dried by vacuum freeze-drying and sprayed with gold by ion sputtering. The cross-sectional structure of the sample was observed with a Quanta200 scanning electron microscope (SEM) (FEI Corporation, Oregon, USA). The scanning magnification was $2400 \times$.

\subsection{Statistical analysis}

Excel 2019 (Microsoft Corporation, State of Washington, USA) and SPSS 22 (SPSS Inc., Chicago, USA) were used for statistical analysis. Origin 2018 (Origin Lab Co., Massachusetts, USA) software was used to prepare images.

\section{Results and discussion}

\subsection{Effects of different frozen storage conditions on the solubility and water holding capacity of gluten protein}

The solubility of gluten protein is the most important factor in its functional properties. The solubility of gluten protein is mainly affected by its hydrophobicity and charge ratio. Because gluten protein contains a high proportion of uncharged amino acids, it has strong hydrophobicity and a large hydrophobic area, resulting in the low overall solubility of the protein ( $\mathrm{Li}$ et al., 2021b). Figure 1A shows the influence of different frozen storage temperatures and times on the solubility of gluten protein. The effects of different storage conditions on the solubility of gluten protein were very different. At the same storage temperature, the solubility of gluten protein decreased with extension of the frozen storage time. The solubility differences among wheat gluten protein stored at $-6{ }^{\circ} \mathrm{C}$ for $10 \mathrm{~d}, 20 \mathrm{~d}$ and $30 \mathrm{~d}$ were smaller than those among wheat gluten protein stored at other temperatures. However, the lower the frozen storage temperature was, the greater the differences in gluten solubility with different frozen storage times. The solubility of wheat gluten protein decreased with decreasing frozen storage temperatures in the range of $-12{ }^{\circ} \mathrm{C}$ to $-30^{\circ} \mathrm{C}$. This may have been due to the gradual growth of ice crystals during the freezing process, which damaged the structure of wet gluten protein. As a result, the secondary bonds maintaining the structure of the gluten protein were weakened, and the spatial conformation of the gluten protein was changed. The hydrophobic groups inside the gluten protein were exposed to the water phase; thus, the solubility of the gluten protein gradually decreased.

The water holding capacity of protein refers to the ability of protein to absorb and retain water. Retained water refers to the 

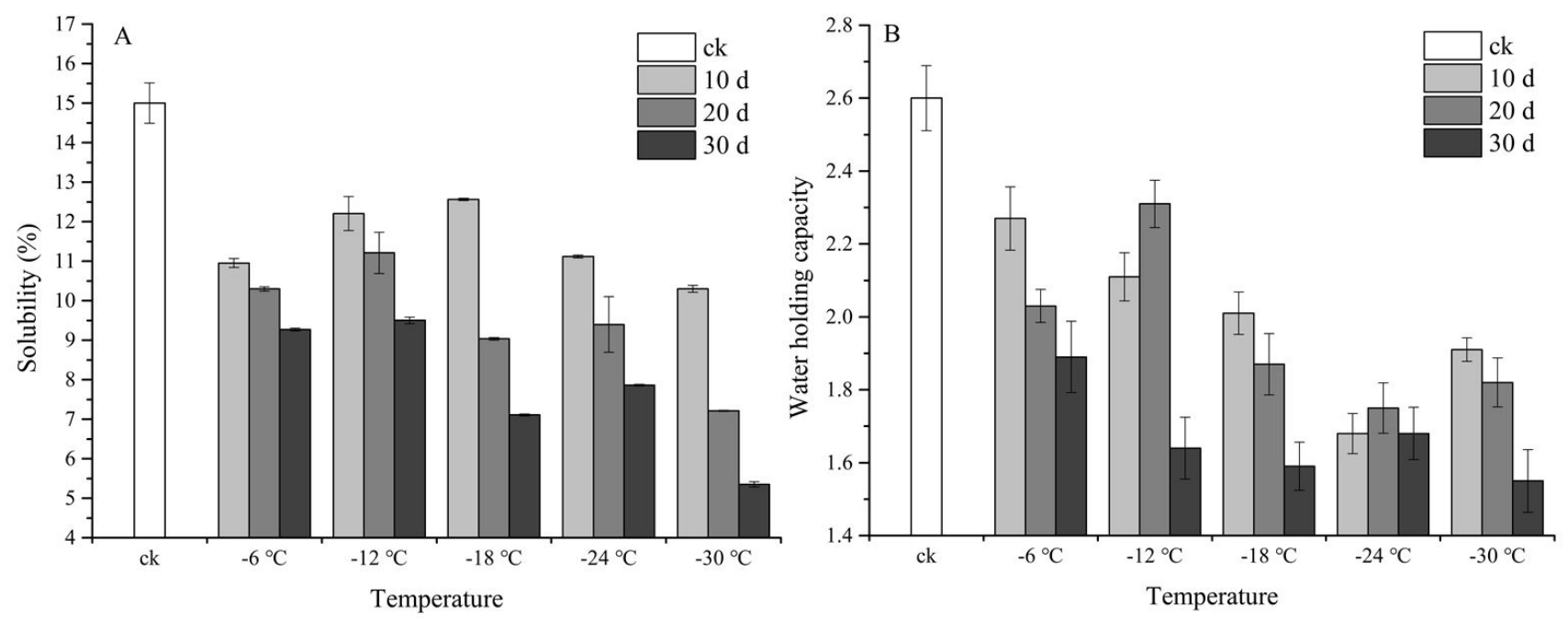

Figure 1. Effects of freezing storage temperature and time on solubility and water holding capacity of gluten protein. A, solubility; B, water holding capacity.

sum of hydrodynamically interacting water (free water), bound water and physically intercepted water. Physical water retention provides the greatest contribution to the water holding capacity of gluten protein, which determines the interaction between protein and water in food systems and has a great influence on the structure, texture, flavor and appearance of food (Nawaz et al., 2021). Therefore, it is important to evaluate the water holding capacity of gluten protein. Figure $1 \mathrm{~B}$ shows the effects of different frozen storage temperatures and times on the water holding capacity of gluten protein. Overall, the water holding capacity of gluten decreased with decreasing frozen storage temperatures, and the water holding capacity of gluten protein with a frozen storage time of $30 \mathrm{~d}$ at all temperatures was lower than that with frozen storage times of $10 \mathrm{~d}$ and $20 \mathrm{~d}$. Recrystallization differed with different storage temperatures and times, and the corresponding effects on gluten protein were also different. Comparatively, the water holding capacity of gluten protein stored at $-12^{\circ} \mathrm{C}$ for $20 \mathrm{~d}$ was the highest. These experimental results are consistent with previous research results (Liu et al., 2011). The reason for this effect may be that the volume of ice crystals increased to some extent under different frozen storage conditions, which caused damage to the structure of the gluten network and changes in the conformation of the gluten protein. As a result, some hydrophobic groups originally hidden in the structure were exposed, and the ability of the gluten network to bind water was weakened, thus reducing the water holding capacity. This phenomenon was consistent with the experimental solubility results.

\subsection{Effects of frozen storage conditions on the foamability and foam stability of gluten protein}

Foamability is an important functional characteristic of gluten protein. The foamability of gluten affects the distribution of bubbles in dough during awakening and initial baking. Evenly distributed and stable bubbles can not only make fermented flour products soft and smooth but also improve the dispersion of flavor substances and make flour products taste better (Zhao et al., 2021). Figure 2 shows that the frozen storage temperature had no significant influence on the protein foamability and foam stability of gluten, although the foamability of gluten protein increased gradually with decreasing storage temperatures when stored for $10 \mathrm{~d}$. However, the effects of the frozen storage time on the foamability and foam stability of gluten were significant at a given storage temperature. With extension of the frozen storage time, the foamability of gluten protein significantly decreased, but the foam stability significantly improved. When stored for $20 \mathrm{~d}$ and $30 \mathrm{~d}$, the foam stability of gluten protein increased gradually with decreasing temperatures. In addition, the foam stability of gluten increased significantly with increasing storage time at a given storage temperature. Some studies have shown that the foamability of proteins is always opposite to their foam stability; that is, proteins with good foaming properties often show poor foam stability (Oetjen et al., 2014). These properties are greatly influenced by the viscosity of the protein itself. This relationship was also confirmed in the tests of the rheological properties of gluten protein. Therefore, with extension of the frozen storage time, the foam stability improved. The structure of the gluten protein became loose after freezing. Various groups in the center of gluten protein were dispersed from each other, and secondary interactions such as hydrogen bonds and hydrophobic forces were destroyed. The spatial configuration of the gluten protein may have changed, the globular protein lost its natural crystallization ability, and the hydration film was destroyed; thus, the gluten protein could not be well expanded and dispersed at the interface between water and air. The longer the frozen storage time was, the more serious the damage. Therefore, the foamability of gluten protein declined.

\subsection{Effects of frozen storage conditions on the rheological properties of gluten protein}

Gluten protein has characteristics of not only a viscous fluid but also an elastic solid, which plays a major role in the 

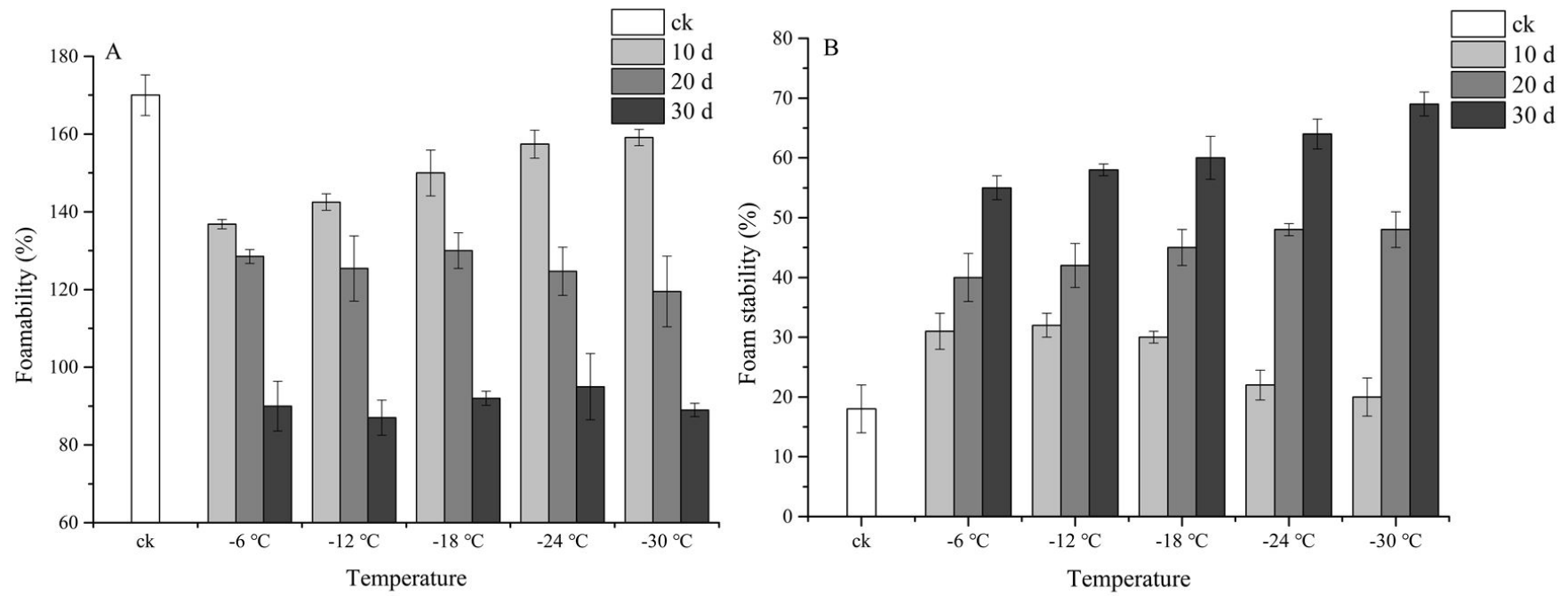

Figure 2. Effects of freezing storage temperature and time on foamability and foam stability of gluten protein. A, foamability; B, foam stability.

rheological properties of dough and affects the processing of dough and the quality of dough products (Xu et al., 2022). G' refers to the elastic nature of a material, namely, the energy recovered by sinusoidal deformation after a vibration cycle, which is also known as the energy storage modulus. $G$ "refers to the viscous nature of matter, which is the energy consumed by sinusoidal deformation and is also known as the loss modulus (Atudorei et al., 2021). As shown in Figure 3, the G' and G" of gluten protein systems with the same frozen storage time showed a decreasing trend with decreasing frozen storage temperatures. However, G' and G" had no significant difference at a given storage temperature. The maximum storage modulus of gluten was $3053.67 \mathrm{~Pa}, 3134.67 \mathrm{~Pa}$, and $3215.67 \mathrm{~Pa}$ and the maximum loss modulus was $1654.00 \mathrm{~Pa}, 1683.34 \mathrm{~Pa}$, and $1712.67 \mathrm{~Pa}$ at a storage temperature of $-6^{\circ} \mathrm{C}$ for $10 \mathrm{~d}, 20 \mathrm{~d}$ and $30 \mathrm{~d}$, respectively. The maximum storage modulus of gluten at $-30{ }^{\circ} \mathrm{C}$ for $10 \mathrm{~d}, 20 \mathrm{~d}$ and $30 \mathrm{~d}$ were $2087.00 \mathrm{~Pa}, 2188.84 \mathrm{~Pa}$, and $2290.67 \mathrm{~Pa}$, and the maximum loss modulus was $1240.33 \mathrm{~Pa}$, 1306.83 Pa, and $1373.33 \mathrm{~Pa}$, respectively. It can be concluded that regardless of the temperature at which gluten was frozen, the storage modulus and loss modulus of gluten increased with extension of the freezing time. This may have been due to the low freezing temperature leading to the depolymerization of gluten protein macromolecular polymers. The aggravation of recrystallization resulted in structural fracturing in the gluten protein network. In addition, the gluten micelles became thin and ruptured. The matrix and network structure of gluten protein was destroyed (Zhang et al., 2021b); thus, the viscoelasticity of gluten changed. The low freezing temperature may have also led to fewer fine ice crystals and more large ice crystals in the dough, weakening the cross-linking effect of gluten and leading to a decrease in the gluten viscoelasticity.

\subsection{Effects of frozen storage conditions on the freezable water content in gluten protein}

The content of freezable water is closely related to the size, quantity and distribution of ice crystals in frozen dough; thus, it is necessary to measure freezable water in gluten. DSC can be used to measure the endothermic enthalpy of ice crystal melting when gluten is close to $0^{\circ} \mathrm{C}$ to reflect its freezable water content (Kontogiorgos et al., 2007). As shown in Figure 4, when the frozen storage time was $20 \mathrm{~d}$, the content of freezable water increased with decreasing temperatures. Semibound water (which is not tightly bound to the polymer) may migrate during frozen storage, causing small ice crystals to aggregate and form larger ice crystals (Alcântara et al., 2020), disrupting the gluten network structure, and leading to water loss and reduced water retention, which increase the content of freezable water. In addition, as shown in Figure 4, the freezable water content in gluten at $-12^{\circ} \mathrm{C}$ was relatively low during storage. The reason may be that less recrystallization occurred during frozen storage at $-12{ }^{\circ} \mathrm{C}$, and a better network structure of the gluten protein phase was maintained; therefore, the content of freezable water was less (Meng et al., 2021a). This somewhat slowed the deterioration of gluten due to moisture crystallization.

\subsection{Effects of frozen storage conditions on the water distribution and migration of gluten protein}

The distribution of water in frozen food is one of the important factors affecting food quality. Low-field nuclear magnetic resonance (LF-NMR) is a fast and nondestructive method to detect water distributions and migration in food. Table 1 shows the water distribution and migration in gluten treated with different frozen storage temperatures and times (He et al., 2020). There were four peaks in the sample $\mathrm{T}_{2}$ spectrum: $\mathrm{T}_{21}, \mathrm{~T}_{22}, \mathrm{~T}_{23}$ and $\mathrm{T}_{24}$. These peaks represented water molecules with different mobilities. The shorter the relaxation time is, the more stable the state of the water. Among the peaks, $\mathrm{T}_{21}(0.01$ $10 \mathrm{~ms}$ ) was tightly bound water, which was the strongly bound layer in which polar groups on the protein molecule surface were closely bound, and its fluidity was the weakest. $\mathrm{T}_{22}(10$ $100 \mathrm{~ms}$ ) was bound water, representing immobilized water indirectly bound to the protein network macromolecules, in which bound water was directly restricted by hydrogen bonds. 

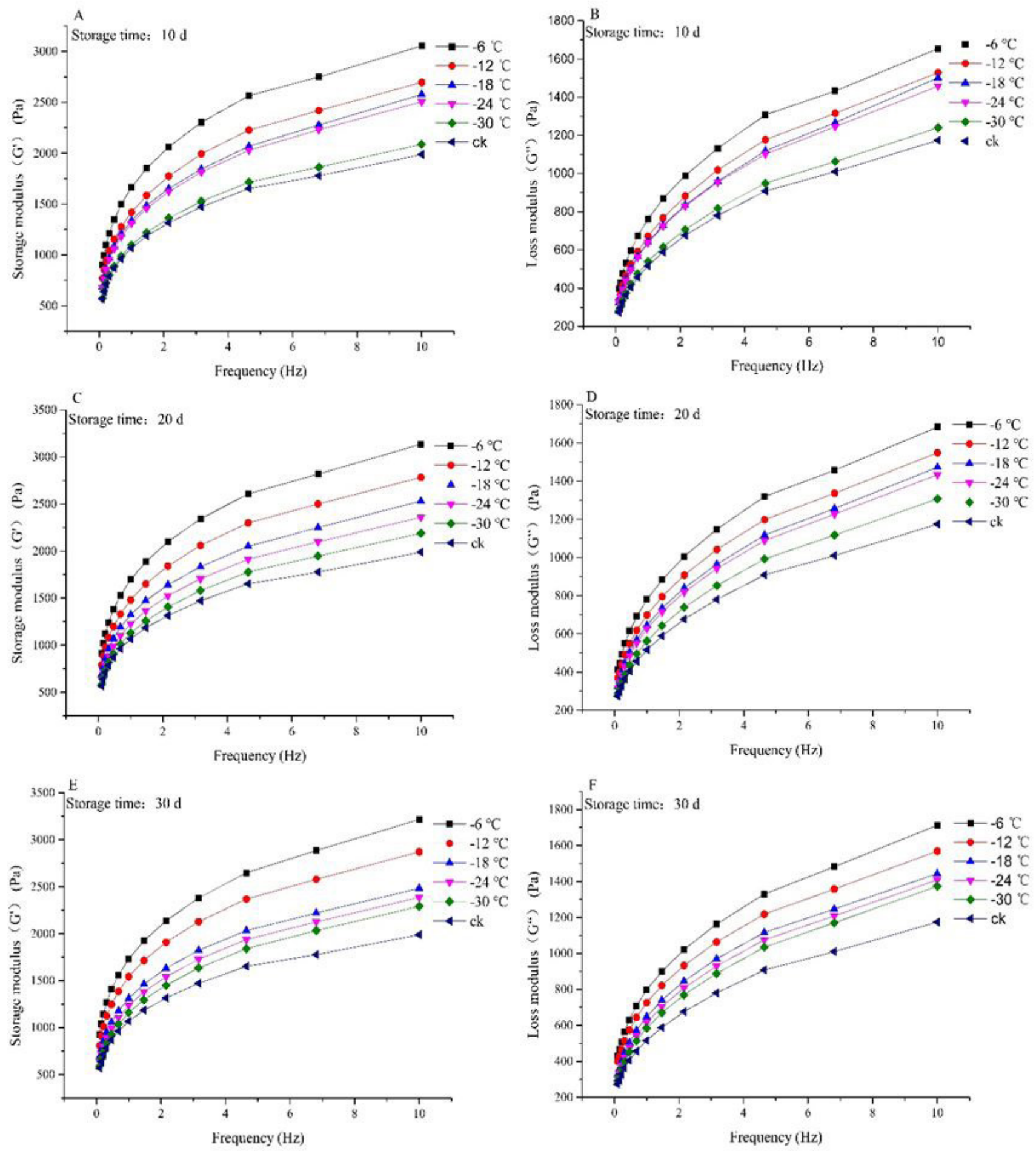

Figure 3. Effects of freezing storage temperature and time on rheological properties of gluten protein. A, C and E were G' for 10d, 20d and 30d respectively. B, D and F were G” for 10d, 20d and 30d respectively.

$\mathrm{T}_{23}$ (100-2000 ms) was low-mobility free water, and $\mathrm{T}_{24}(2000-$ $10000 \mathrm{~ms}$ ) was high mobility free water. $\mathrm{T}_{23}$ and $\mathrm{T}_{24}$ were free water adsorbed to the surface of the protein molecules and had high fluidity (Zheng et al., 2020). The relaxation times $\mathrm{T}_{21}$, $\mathrm{T}_{22}, \mathrm{~T}_{23}$ and $\mathrm{T}_{24}$ shifted to the left or right, indicating that the moisture in the gluten migrated. $\mathrm{A}_{21}, \mathrm{~A}_{22}, \mathrm{~A}_{23}$ and $\mathrm{A}_{24}$ are the peak area ratios of the four peaks representing different water contents. The changes in the peak area ratios $A_{21}, A_{22}, A_{23}$ and $\mathrm{A}_{24}$ indicate that the proportions of water in different states changed. As seen from Table 1, with extension of the frozen 
Table 1. Changes of relaxation time (T2) and water fraction (A2) of wheat gluten protein at different freezing conditions.

\begin{tabular}{|c|c|c|c|c|c|c|c|c|c|}
\hline \multirow{2}{*}{$\begin{array}{c}\text { Storage time } \\
\text { (d) }\end{array}$} & \multirow{2}{*}{$\begin{array}{c}\text { Storage } \\
\text { temperature } \\
\left({ }^{\circ} \mathrm{C}\right)\end{array}$} & \multicolumn{4}{|c|}{$\mathrm{T}_{2}(\mathrm{~ms})$} & \multicolumn{4}{|c|}{$\mathrm{A}_{2}(\%)$} \\
\hline & & $\mathrm{T}_{21}$ & $\mathrm{~T}_{22}$ & $\mathrm{~T}_{23}$ & $\mathrm{~T}_{24}$ & $\mathrm{~A}_{21}$ & $\mathrm{~A}_{22}$ & $\mathrm{~A}_{23}$ & $\mathrm{~A}_{24}$ \\
\hline $\mathrm{ck}$ & $\mathrm{ck}$ & 2.01 & 37.65 & 467.17 & - & 11.62 & 85.30 & 3.08 & - \\
\hline \multirow[t]{5}{*}{10} & -6 & 2.01 & 43.29 & 464.16 & 4977.24 & 11.23 & 84.95 & 3.82 & 0.01 \\
\hline & -12 & 2.01 & 43.29 & 932.60 & 4328.76 & 10.03 & 80.53 & 9.14 & 0.30 \\
\hline & -18 & 2.31 & 49.77 & 1072.27 & 5722.37 & 9.71 & 82.13 & 8.09 & 0.07 \\
\hline & -24 & 2.01 & 43.29 & 811.13 & 4977.02 & 9.29 & 83.17 & 7.41 & 0.14 \\
\hline & -30 & 2.31 & 49.77 & 932.60 & 6579.33 & 9.93 & 82.93 & 7.13 & 0.02 \\
\hline \multirow[t]{5}{*}{20} & -6 & 1.75 & 32.75 & 533.67 & - & 11.11 & 86.10 & 2.78 & - \\
\hline & -12 & 2.01 & 32.75 & 533.67 & - & 11.37 & 84.04 & 4.59 & - \\
\hline & -18 & 1.52 & 37.65 & 533.67 & - & 12.41 & 82.53 & 5.06 & - \\
\hline & -24 & 1.15 & 37.65 & 533.67 & - & 14.41 & 82.59 & 3.00 & - \\
\hline & -30 & 1.52 & 37.65 & 613.59 & - & 13.70 & 82.13 & 3.89 & - \\
\hline \multirow[t]{5}{*}{30} & -6 & 1.75 & 37.65 & 533.67 & 4328.76 & 12.03 & 83.53 & 4.29 & 0.15 \\
\hline & -12 & 1.32 & 37.65 & 613.59 & 2477.08 & 12.21 & 82.30 & 5.16 & 0.34 \\
\hline & -18 & 1.15 & 37.65 & 705.48 & 4977.02 & 14.15 & 82.05 & 3.64 & 0.16 \\
\hline & -24 & 1.15 & 37.65 & 613.59 & 3764.94 & 12.64 & 83.81 & 3.34 & 0.21 \\
\hline & -30 & 1.32 & 37.65 & 613.59 & 3764.94 & 12.04 & 82.56 & 5.15 & 0.25 \\
\hline
\end{tabular}

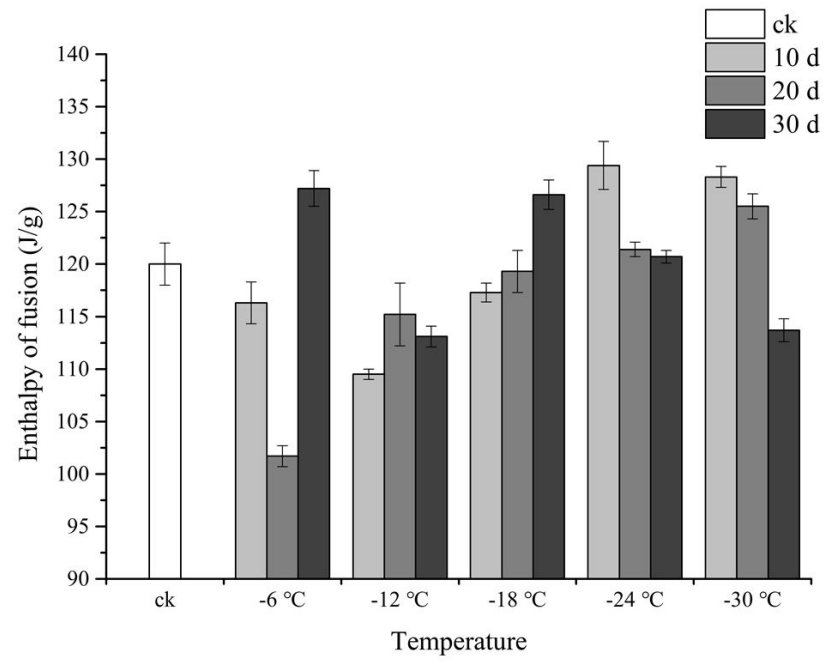

Figure 4. Effects of freezing storage temperature and freezing storage time on melting enthalpy of gluten protein.

storage time, compared with samples stored for 10 days, the relaxation times $\mathrm{T}_{21}, \mathrm{~T}_{22}, \mathrm{~T}_{23}$ and $\mathrm{T}_{24}$ of gluten stored for 20 and 30 days shifted to the left overall, indicating that water molecules were bound more closely with the polar groups on the protein surface. For samples stored in the range from $-12{ }^{\circ} \mathrm{C}$ to $-30{ }^{\circ} \mathrm{C}$, when the storage time was longer, the proportion of $\mathrm{A}_{21}$ was higher and the proportion of $\mathrm{A}_{23}$ was lower compared with those of nonfrozen storage samples and samples stored at $-6^{\circ} \mathrm{C}$. In other words, the longer the storage time is, the greater the increase in tightly bound water, while low-mobility free water decreases. However, after 30 days of storage, the proportion of $\mathrm{A}_{24}$ in samples stored at different temperatures increased significantly, indicating that high-mobility free water increased.

\subsection{Microstructure of gluten proteins}

Wheat gluten protein plays a role in the network of dough. The microstructure of wet gluten protein after frozen storage can be observed by scanning electron microscopy (SEM). The microstructure of gluten protein presented a threedimensional network structure in which holes were formed after the dehydration of ice crystals. The microstructures of gluten proteins at different storage temperatures and different storage times are shown in Figure 5. With extension of the freezing time, gluten protein pores showed an obvious increasing trend. This may have been due to water migration and ice recrystallization in the dough during freezing. In the process of dough freezing and storage, large ice crystals generated by ice crystal formation and recrystallization caused mechanical damage to the dough, resulting in an increase in gluten network holes. Comparing samples stored at different temperatures with the same storage time, the gluten protein networks in samples stored at $-24{ }^{\circ} \mathrm{C}$ and $-30^{\circ} \mathrm{C}$ showed serious breakage. When the frozen storage temperature was $-30^{\circ} \mathrm{C}$, the gluten protein network exhibited large fragments, the gluten protein micelles were rougher than those at other frozen storage temperatures, and more fragments appeared (Xue et al., 2021). Compared with samples stored at other temperatures, the network of gluten stored at $-12{ }^{\circ} \mathrm{C}$ was tighter, the hole size was more uniform, and the protein skeleton was smoother. This may have been because when the dough was frozen at $-6^{\circ} \mathrm{C}$, it was first subjected to ultralow-temperature quick freezing at $-40^{\circ} \mathrm{C}$, and then when it was frozen at $-6^{\circ} \mathrm{C}$, bound water migrated due to temperature fluctuations, the gluten protein pores became large, and the protein skeleton became rough (Zhang et al., 2021a). However, at $-12^{\circ} \mathrm{C}$, although free water was frozen, some bound water was not completely frozen. This had a good protective effect on gluten protein. Therefore, the protein structure showed a better state than those stored at other temperatures. 

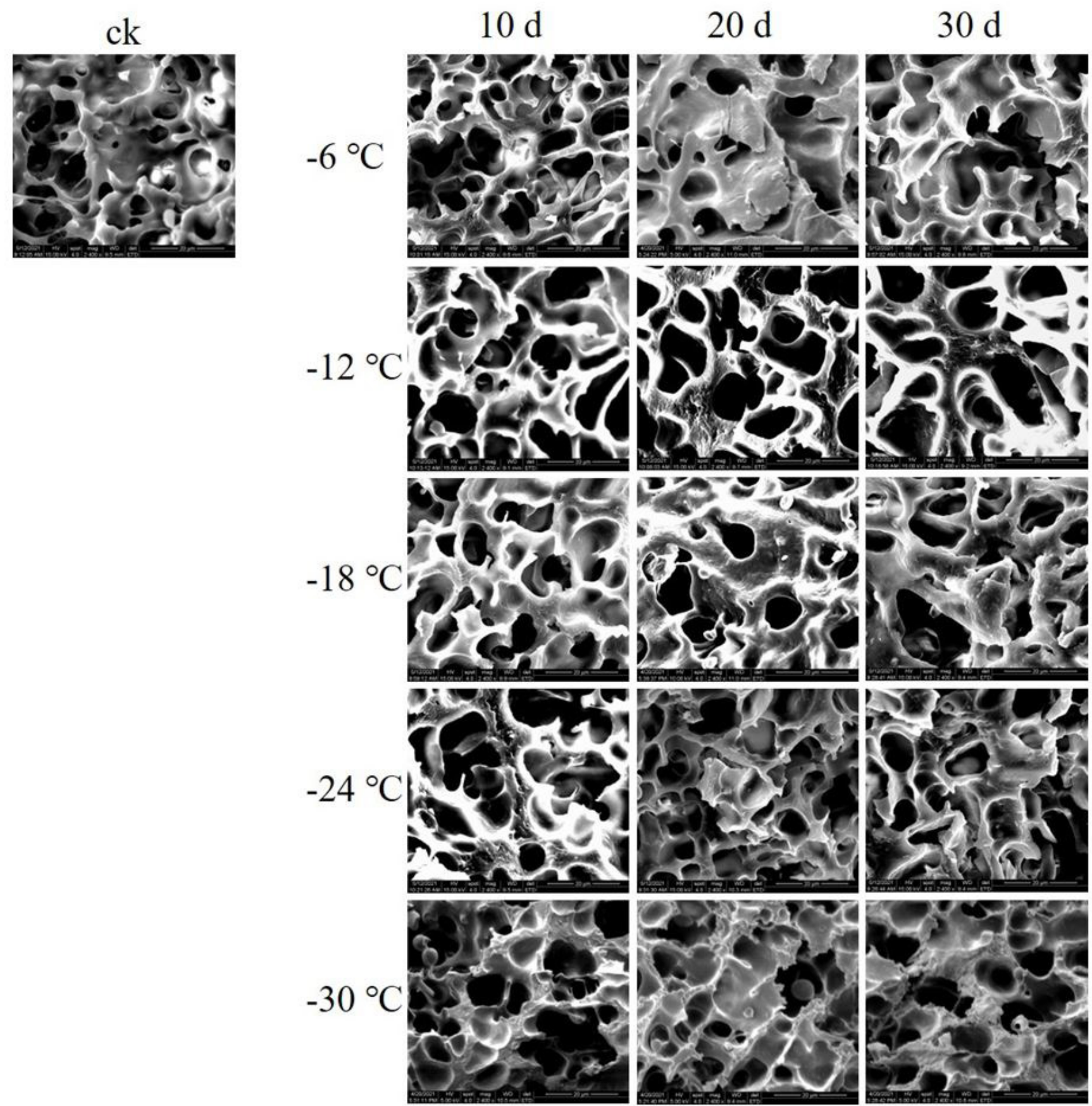

Figure 5. Microstructure of gluten protein at different freezing storage temperature and time.

\section{Conclusion}

Studies have found that the functional properties of wheat gluten in frozen dough change significantly, and the functional properties of gluten also change under different freezing temperatures and freezing times. The solubility and water holding capacity of gluten protein showed a downward trend with the decrease in the frozen storage temperature and the extension of the frozen storage time. The storage modulus $\left(G^{\prime}\right)$ and loss modulus (G") of gluten decreased with decreasing frozen storage temperatures and storage time. The foaming ability and foam stability of gluten were not affected by the frozen storage temperature but decreased with extension of the frozen storage time. Compared with gluten at other freezing temperatures, gluten at $-12{ }^{\circ} \mathrm{C}$ had a lower frozen water content. LF-NMR results showed that the moisture in gluten migrated under different freezing temperatures and times, indicating that the structure of the gluten protein changed. It was observed under a scanning electron microscope that the structure of gluten protein was more complete and that the overall state was smoother at a frozen storage temperature of $12{ }^{\circ} \mathrm{C}$. Wheat gluten protein is the main 
component that affects the quality of flour products. Freezing temperatures that were too low and prolonged frozen storage times caused more serious damage. As a result, in the process of making frozen flour products, storage temperatures that are too low and storage times that are too long should be avoided as much as possible to maintain the quality of flour products.

\section{Acknowledgements}

This work was financed by Central government guiding local scientific and technological development projects (No. 2021), the Program of Xinxiang Major Scientific and Technological Project (No. ZD2020003); and Science and Technology Projects in Henan Province (grant number 19A550007).

\section{References}

Alcântara, R. G., Carvalho, R. A., \& Vanin, F. M. (2020). Evaluation of wheat flour substitution type (corn, green banana and rice flour) and concentration on local dough properties during bread baking. Food Chemistry, 326, 126972. http://dx.doi.org/10.1016/j. foodchem.2020.126972. PMid:32422510.

Atudorei, D., Atudorei, O., \& Codină, G. G. (2021). Dough rheological properties, microstructure and bread quality of wheat-germinated bean composite flour. Foods, 10(7), 1542. http://dx.doi.org/10.3390/ foods10071542. PMid:34359411.

Bhattacharya, M., Langstaff, T. M., \& Berzonsky, W. A. (2003). Effect of frozen storage and freeze-thaw cycles on the rheological and baking properties of frozen doughs. Food Research International, 36(4), 365-372. http://dx.doi.org/10.1016/S0963-9969(02)00228-4.

Feng, W., Ma, S., \& Wang, X. (2020). Quality deterioration and improvement of wheat gluten protein in frozen dough. Grain \& Oil Science and Technology, 3(1), 29-37. http://dx.doi.org/10.1016/j. gaost.2020.02.001

He, Y., Guo, J., Ren, G., Cui, G., Han, S., \& Liu, J. (2020). Effects of konjac glucomannan on the water distribution of frozen dough and corresponding steamed bread quality. Food Chemistry, 330, 127243. http://dx.doi.org/10.1016/j.foodchem.2020.127243. PMid:32521403.

Jiang, J., Gao, H., Zeng, J., Zhang, L., Wang, F., Su, T., \& Li, G. (2021). Determination of subfreezing temperature and gel retrogradation characteristics of potato starch gel. Lebensmittel-Wissenschaft + Technologie, 149, 112037. http://dx.doi.org/10.1016/j.lwt.2021.112037.

Kontogiorgos, V., Goff, H. D., \& Kasapis, S. (2007). Effect of aging and ice structuring proteins on the morphology of frozen hydrated gluten networks. Biomacromolecules, 8(4), 1293-1299. http://dx.doi. org/10.1021/bm0610471. PMid:17341113.

Li, Y., Li, C., Ban, X., Cheng, L., Hong, Y., Gu, Z., \& Li, Z. (2021b). New insights into the alleviating role of starch derivatives on dough quality deterioration caused by freeze. Food Chemistry, 362, 130240. http://dx.doi.org/10.1016/j.foodchem.2021.130240. PMid:34119950.

Liu, G. Q., Liu, X. J., Li, L., \& Li, B. (2011). Effects of Frozen Storage Time on the Functional Properties of Frozen Wheat Gluten. Advanced Materials Research, 236-238, 2647-2650. http://dx.doi.org/10.4028/ www.scientific.net/AMR.236-238.2647.

Liu, T., Gao, X., Li, L., Du, D., Cheng, X., Zhao, Y., Liu, Y., \& Li, X. (2016). Effects of HMW-GS at Glu-B1 locus on the polymerization of glutenin during grain development and on the secondary and micro-structures of gluten in wheat (Triticum aestivum L.). Journal of Cereal Science, 72, 101-107. http://dx.doi.org/10.1016/j.jcs.2016.10.007.
Lu, L., Yang, Z., Guo, X. N., Xing, J. J., \& Zhu, K. X. (2021). Effect of $\mathrm{NaHCO}_{3}$ and freeze-thaw cycles on frozen dough: from water state, gluten polymerization and microstructure. Food Chemistry, 358, 129869. http://dx.doi.org/10.1016/j.foodchem.2021.129869. PMid:33933952.

Meng, K., Gao, H., Zeng, J., Li, G., \& Su, T. (2021a). Effect of subfreezing storage on the quality and shelf life of frozen fermented dough. Journal of Food Processing and Preservation, 45(3), e15249. http:// dx.doi.org/10.1111/jfpp.15249.

Meng, K., Gao, H., Zeng, J., Zhao, J., Qin, Y., Li, G., \& Su, T. (2021b). Rheological and microstructural characterization of wheat dough formulated with konjac glucomannan. Journal of the Science of Food and Agriculture, 101(10), 4373-4379. http://dx.doi.org/10.1002/ jsfa.11078. PMid:33417243.

Nawaz, A., Alhilali, A. H. T., Li, E., Khalifa, I., Irshad, S., Walayat, N., Chen, L., Wang, P., \& Tan, Z. Y. (2021). The effects of gluten protein substation on chemical structure, crystallinity, and $\mathrm{Ca}$ in vitro digestibility of wheat-cassava snacks. Food Chemistry, 339, 127875. http://dx.doi.org/10.1016/j.foodchem.2020.127875. PMid:32866701.

Oetjen, K., Bilke-Krause, C., Madani, M., \& Willers, T. (2014). Temperature effect on foamability, foam stability, and foam structure of milk. Colloids and Surfaces. A, Physicochemical and Engineering Aspects, 460, 280-285. http://dx.doi.org/10.1016/j.colsurfa.2014.01.086.

Wang, P., Jin, Z., \& Xu, X. (2015). Physicochemical alterations of wheat gluten proteins upon dough formation and frozen storage - A review from gluten, glutenin and gliadin perspectives. Trends in Food Science \& Technology, 46(2), 189-198. http://dx.doi.org/10.1016/j. tifs.2015.10.005.

Wang, P., Tao, H., Wu, F., Yang, N., Chen, F., Jin, Z., \& Xu, X. (2014). Effect of frozen storage on the foaming properties of wheat gliadin. Food Chemistry, 164, 44-49. http://dx.doi.org/10.1016/j. foodchem.2014.05.010. PMid:24996303.

Xu, K., Chi, C., She, Z., Liu, X., Zhang, Y., Wang, H., \& Zhang, H. (2022). Understanding how starch constituent in frozen dough following freezing-thawing treatment affected quality of steamed bread. Food Chemistry, 366, 130614. http://dx.doi.org/10.1016/j. foodchem.2021.130614. PMid:34304137.

Xue, F., Xie, Y., Li, C., Wang, S., \& Liu, X. (2021). Prevention of frozendough from deterioration with incorporation of glutenin-polyphenols conjugates prepared by ultrasound. Lebensmittel-Wissenschaft + Technologie, 151, 112141. http://dx.doi.org/10.1016/j.lwt.2021.112141.

Yang, J., Zhang, B., Zhang, Y., Rasheed, M., Gu, S., \& Guo, B. (2021a). Effect of freezing rate and frozen storage on the rheological properties and protein structure of non-fermented doughs. Journal of Food Engineering, 293, 110377. http://dx.doi.org/10.1016/j. jfoodeng.2020.110377.

Zhang, B., Omedi, J. O., Zheng, J., Huang, W., Jia, C., Zhou, L., Zou, Q., Li, N., \& Gao, T. (2021a). Exopolysaccharides in sourdough fermented by Weissella confusa QS813 protected protein matrix and quality of frozen gluten-red bean dough during freeze-thaw cycles. Food Bioscience, 43, 101180. http://dx.doi.org/10.1016/j. fbio.2021.101180.

Zhang, L., Guan, E., Yang, Y., Liu, Y., Zhang, T., \& Bian, K. (2021b). Impact of wheat globulin addition on dough rheological properties and quality of cooked noodles. Food Chemistry, 362, 130170. http:// dx.doi.org/10.1016/j.foodchem.2021.130170. PMid:34091164.

Zhang, Y., Li, Y., Liu, Y., \& Zhang, H. (2018). Effects of multiple freezethaw cycles on the quality of frozen dough. Cereal Chemistry, 95(4), 499-507. http://dx.doi.org/10.1002/cche.10053.

Zhang, Y., Li, Y., Wang, H., Oladejo, A. O., Zhang, H., \& Liu, X. (2020a). Effects of ultrasound-assisted freezing on the water migration of 
dough and the structural characteristics of gluten components. Journal of Cereal Science, 94, 102893. http://dx.doi.org/10.1016/j. jcs.2019.102893.

Zhang, Y., Zhang, Y., Ai, Z., \& Zhang, H. (2020b). Thermal, rheological properties and microstructure of hydrated gluten as influenced by antifreeze protein from oat (Avena sativa L.). Journal of Cereal Science, 93, 102934. http://dx.doi.org/10.1016/j.jcs.2020.102934.

Zhao, B., Fu, S., Li, H., Li, H., Wang, Y., Li, Z., \& Liu, C. (2021). Quality evaluation of steam reheated frozen steamed bread. LebensmittelWissenschaft + Technologie, 150, 112074. http://dx.doi.org/10.1016/j. lwt.2021.112074.
Zhao, L., Liu, X., Hu, Z., Li, L., \& Li, B. (2016). Molecular Structure Evaluation of Wheat Gluten during Frozen Storage. Food Biophysics, 12(1), 60-68. http://dx.doi.org/10.1007/s11483-016-9463-2.

Zheng, M., Lin, Y., Wu, H., Zeng, S., Zheng, B., Zhang, Y., \& Zeng, H. (2020). Water migration depicts the effect of hydrocolloids on the structural and textural properties of lotus seed starch. Food Chemistry, 315, 126240. http://dx.doi.org/10.1016/j.foodchem.2020.126240. PMid:31991255.

Zhou, R., Sun, J., Qian, H., Li, Y., Zhang, H., Qi, X., \& Wang, L. (2020). Effect of the frying process on the properties of gluten protein of you-tiao. Food Chemistry, 310, 125973. http://dx.doi.org/10.1016/j. foodchem.2019.125973. PMid:31837526. 